\title{
Dry Matter Production and Nutritional Status of Sunflower Grown in Nutrient Solution under Macronutrient Omission
}

\author{
Allan Nunes Alves, Felipe Guedes de Souza, Lúcia Helena Garófalo Chaves*, \\ Ana Carolina Feitosa de Vasconcelos \\ Department of Agricultural Engineering, Federal University of Campina Grande, Campina Grande, Brazil \\ Email: allan.1nunes@gmail.com, felipeguedes.eng@gmail.com, *lhgarofalo@hotmail.com, ana3carol@yahoo.com.br
}

How to cite this paper: Alves, A.N., de Souza, F.G., Chaves, L.H.G. and de Vasconcelos, A.C.F. (2018) Dry Matter Production and Nutritional Status of Sunflower Grown in Nutrient Solution under Macronutrient Omission. Agricultural Sciences, 9, 1479-1486.

https://doi.org/10.4236/as.2018.911103

Received: November 1, 2018

Accepted: November 24, 2018

Published: November 27, 2018

Copyright $\odot 2018$ by authors and Scientific Research Publishing Inc. This work is licensed under the Creative Commons Attribution International License (CC BY 4.0).

http://creativecommons.org/licenses/by/4.0/

\begin{abstract}
The objective of this study was to evaluate the effect of omission of macronutrients on dry matter production and on the nutritional status of sunflower cv. BRS 122. The experiment was carried out in a greenhouse, in randomized blocks, with seven treatments corresponding to the Hoagland \& Arnon standard solution (1950) and the individual omission of N, P, K, Ca, Mg and S, in three replicates. After 50 days of sowing, the dry matter and the nutritional status of the plants were evaluated. The omission of $\mathrm{N}, \mathrm{P}, \mathrm{K}, \mathrm{Ca}, \mathrm{Mg}$ and $\mathrm{S} \mathrm{li}$ mited the dry mass production of sunflower cv. BRS 122 in relation to the complete solution, besides causing nutritional imbalance due to the interaction between the nutrients. The omission of the macronutrients $\mathrm{K}, \mathrm{Ca}$, and $\mathrm{Mg}$ caused the higher imbalances in the plants, highlighting the elevated $\mathrm{N}$ contents in these treatments comparing to the complete solution.
\end{abstract}

\section{Keywords}

Helianthus annuus, Nutritional Diagnosis, Omission of Nutrients

\section{Introduction}

Sunflower (Helianthus annuus L.) is an oleaginous plant with great market prospects, accounting for around $13 \%$ of all vegetable oil produced in the world. It is a crop of broad adaptability, high tolerance to drought and grain producer. Seeds are rich in oil, with excellent industrial and nutritional quality, and their use as edible oil is the main use [1], and some varieties produced by hybridization reach amounts greater than 50\% [2]. In addition, the sunflower plant, grains, crop residues and by-products generated in the extraction of oil can be 
used in animal feed.

The sunflower crop extracts a large amount of nutrients from the soil compared to other oilseeds; therefore, it is important to provide nutrients in adequate quantities, avoiding the lack or excess of a certain element [3]. Nitrogen is absorbed in greater quantity by the sunflower in the period from the beginning of the formation of the chapter until the flowering. However, this crop is highly demanding in potassium, being consumed by plants in amounts much higher than those required of nitrogen and phosphorus.

Studies involving the relationships between accumulation of nutrient in plants generate important information for understanding the nutritional status and crop demands, since this information can be used as a reference to calculate the amount of nutrients to be supplied to the plants through fertilization [4]. According to [5], the interaction between nutrients in crop plants occurs when the supply or omission of one nutrient affects the absorption and utilization of other nutrients. In plant nutrition experiments, nutrient interactions can be identified taking into consideration the effects of increasing or omission of nutrient concentrations on the uptake of other nutrients and corresponding plant growth.

Plants require essential nutrients for normal functioning and growth. A plant's sufficiency range is the nutrient amount necessary to meet the plant's nutritional needs and maximize growth. The width of this range depends on individual plant species and the particular nutrient. Nutrient levels outside of a plant's sufficiency range cause overall crop growth and health to decline due to either a deficiency or toxicity. Nutrient deficiency occurs when an essential nutrient is not available in sufficient quantity to meet the requirements of a growing plant. On the other hand, toxicity occurs when a nutrient is in excess of plant needs and decreases plant growth or quality [6].

The science of hydroponics is characterized by the fact that soil is not needed for plant growth but the elements, minerals and nutrients that soil contains are required. As soil is simply the holder of the nutrients, a place where the plant roots traditionally live and a base support for the plant structure, by eliminating the soil, it also eliminates soil borne diseases and weeds and gains precise control over the plant's nutritional requirements. Application of this culture technique can be considered as an alternative approach for large-scale production of some desired and valuable crops [7].

There are several advantages of hydroponic cultivation; therefore, each advantage is associated with a cultivation system. For example, the best control over the composition of nutrients supplied to plants is a great advantage for research with Mineral Nutrition of Plants. The higher productivity achieved with hydroponically cultivated plants is of paramount importance for cultivation on a commercial scale [8].

In this sense, hydroponic cultivation can optimize yield; however, it is important that the crop is cultivated in a way that fully meets its nutritional requirement, because nutritional deficiency affects vegetative development and photo- 
synthetic capacity, which may in turn affect production [9].

In this context, the objective of this study was to evaluate the effect of omission of macronutrients on dry matter production and on the nutritional status of sunflower plants grown in nutrient solution.

\section{Material and Methods}

The experiment was carried out under greenhouse conditions of the Academic Unit of Agricultural Engineering of the Federal University of Campina Grande, from June to August of 2016, using nutrient solution in sunflower plants of the cultivar BRS122.The cultivar BRS 122 is a variety of sunflower that stands out for the precocity and low size. It shows flowering from 53 to 60 days and maturation from 85 to 100 days, an average of $60 \mathrm{~g}$ of weight of a thousand achenes, and oil content from $40 \%$ to $44 \%$, according to the edaphoclimatic conditions.

The statistical design was completely randomized, with seven treatments and three replicates, as follows: T1-complete solution (control) (with macro and micronutrients) according to [10], T2-nutritive solution with omission of nitrogen $(\mathrm{N})$, T3-nutritive solution with omission of phosphorus (P), T4-nutritive solution with omission of potassium (K), T5-nutritive solution with omission of calcium (Ca), T6-nutritive solution with omission of magnesium (Mg), T7-nutritive solution with omission of sulfur (S), totaling 21 experimental units with a sunflower cultivar BRS 122 plant.

The sunflower BRS-122 cultivar plants used in the experiment were obtained via seeds and germinated in phenolic sponges conditioned in a plastic container (disposable cups), with a capacity of $50 \mathrm{ml}$ containing deionized water until the surface of the sponge. Six days after germination, the seedlings were submitted to $10 \%$ of the ionic strength of complete nutrient solution [10] under constant aeration in order to seedlings' adaptation. When it was observed the formation of four leaves in the seedlings, they were transferred to one-liter pots and submitted to treatment solutions, with $40 \%$ and $100 \%$ of the ionic strength in the second and third weeks, respectively. The pots were capped with styrofoam with a hole in the center of them for the fixation of the plants and another hole in the end for the entrance of air.

At the end of the experiment, at 50 DAS, the plants were harvested, packed in paper bags, properly labeled and taken for drying in a forced circulation oven at $65^{\circ} \mathrm{C}$, until reaching constant weight, obtaining the weight of the dry matter of the area. After this procedure, the plant material was crushed and sent to the Soil Laboratory of the Federal University of Viçosa (UFV) to carry out chemical analyzes regarding its $\mathrm{N}, \mathrm{P}, \mathrm{K}, \mathrm{Ca}, \mathrm{Mg}$ and $\mathrm{S}$ nutrient concentration. From these concentrations and the dry matter amount, the content of the nutrients was calculated, evaluating the nutritional state of the plant.

The data were submitted to analysis of variance and comparison of means, using the Tukey test at $1 \%$ level of significance by applying the SISVAR software [11]. 


\section{Results and Discussion}

The dry matter $(\mathrm{DM})$ of the plants as well as the nitrogen $(\mathrm{N})$, phosphorus $(\mathrm{P})$, potassium $(\mathrm{K})$, calcium $(\mathrm{Ca})$, magnesium $(\mathrm{Mg})$ and sulfur $(\mathrm{S})$ levels in plant tissues of sunflower plants were significantly influenced at $1 \%$ probability level as a function of treatments (Table 1).

Nitrogen deficiency in plants compromises several physiological processes and is associated with lower chlorophyll production, causing chloroplast modification, affecting cell division and, consequently, plant growth. Therefore, the omission of $\mathrm{N}$ significantly reduced the dry matter production of the plants $(0.32$ g) that is, decreased by $98.56 \%$ in relation to the complete treatment $(22.23 \mathrm{~g})$. These data corroborate [12], who observed a reduction of around $94 \%$ in the dry matter of sunflower var. Catissol-01 submitted to omission of $\mathrm{N}$.

Phosphorus-deficient plants have a delayed growth because this nutrient is linked to the structural function and energy transfer and storage process [13], affecting several metabolic processes, such as protein and nucleic acid synthesis [14]. Thus, there was a decrease in the dry matter of sunflower plants cultivated in nutrient solution with omission of $\mathrm{P}(0.65 \mathrm{~g})$ around $97.33 \%$ in relation to the complete treatment.

The plants were affected by the omission of $\mathrm{K}$, being the result of the dry matter, $0.82 \mathrm{~g}$, significantly inferior to the plants that received the complete treatment. Adequate $\mathrm{K}$ level is essential for the efficient use of $\mathrm{N}$ in crop plants because it plays an important role in plant metabolism processes. Potassium could be involved with $\mathrm{NO}_{3}^{-}$uptake, that can be affected through the influence of $\mathrm{K}$ on the translocation of photosynthetic assimilates, needed to support this active uptake process (Fageria, 2001).

Calcium is an essential macronutrient for plants [15] performing the important function of cell wall stabilization [16]. The lack of this element is characterized by reduced growth of meristematic tissues [14]. Thus, the omission of calcium in sunflower plants presented decrease in dry matter, $0.42 \mathrm{~g}$, in relation to the complete treatment.

Magnesium is essential for the normal development of plants, since it acts on photosynthesis and on various metabolic processes in plants; therefore, its deficiency limits plant growth. The omission of magnesium in the sunflower crop affected the dry matter production of the plants, $9.31 \mathrm{~g}$, decreasing significantly in relation to the complete treatment.

Table 1. Summary of variance analysis for dry matter data and nutrient content in sunflower plants as a function of treatments.

\begin{tabular}{ccccccccc}
\hline \multirow{2}{*}{$\begin{array}{c}\text { Source } \\
\text { of variation }\end{array}$} & DF & DM & \multicolumn{7}{c}{ Mean Square } \\
\cline { 5 - 9 } & & & $\mathrm{N}$ & $\mathrm{P}$ & $\mathrm{K}$ & $\mathrm{Ca}$ & $\mathrm{Mg}$ & $\mathrm{S}$ \\
\hline Treatment & 6 & $246.82^{\star *}$ & $2.88^{\star *}$ & $0.13^{* *}$ & $3.32^{\star *}$ & $2.14^{* *}$ & $1.23^{* *}$ & $0.07^{\star *}$ \\
$\mathrm{CV}(\%)$ & & 40.42 & 7.52 & 18.80 & 13.26 & 17.92 & 3.03 & 3.56 \\
\hline
\end{tabular}

$\mathrm{DF}=$ Degree of Freedom, ${ }^{\mathrm{ns}},{ }^{*}$ and ${ }^{* *}$ no significant, significant to the $5 \%$ and $1 \%$ level, respectively. CV $=$ Variation coefficient. 
The same behavior was observed with the omission of sulfur, producing 12.04 $\mathrm{g}$ of dry matter of the sunflower plants. This element participates in essential amino acids and its deficiency interrupts the synthesis of proteins and sugars, also occurring accumulation of N-organic and $\mathrm{N}^{-\mathrm{NO}_{3}}$, resulting in plants of smaller size and number of leaves [13].

In spite of this, magnesium and sulfur omissions affected less the dry matter production of sunflower plants in nutrient solution. Prado and Leal [12], working with omission of magnesium and sulfur in sunflower plants, observed that there was no detrimental effect on the dry matter of these plants in relation to the complete treatment.

In general, the dry matter production of plants caused by the omission of nutrients, $\mathrm{Ca}, \mathrm{P}, \mathrm{K}, \mathrm{Mg}$ and $\mathrm{S}$, compared to the complete treatment (complete solution) decreased $97.27 \% ; 97.33 \% ; 96.61 \% ; 61.57 \%$ and $50.28 \%$, respectively.

The omission of $\mathrm{N}$ in the nutrient solution affected other nutrients, with a significant reduction in $\mathrm{N}\left(1.73 \mathrm{dag} \cdot \mathrm{kg}^{-1}\right)$ and $\mathrm{K}\left(0.52 \mathrm{dag} \cdot \mathrm{kg}^{-1}\right)$, and with an increase in $\mathrm{Mg}\left(1.55 \mathrm{dag} \cdot \mathrm{kg}^{-1}\right)$ and $\mathrm{S}\left(0.50 \mathrm{dag} \cdot \mathrm{kg}^{-1}\right)$ contents, compared to the complete treatment. However, the omission of $\mathrm{N}$ did not affect the levels of $\mathrm{P}$ $\left(0.58 \mathrm{dag} \cdot \mathrm{kg}^{-1}\right)$ and $\mathrm{Ca}\left(2.91 \mathrm{dag} \cdot \mathrm{kg}^{-1}\right)$ found in tissues of sunflower plants. According to Figure 1, the highest concentrations of $\mathrm{N}$ were observed in plants grown in solution with the omission of $\mathrm{K}\left(3.97 \mathrm{dag} \cdot \mathrm{kg}^{-1}\right), \mathrm{Ca}\left(4.03 \mathrm{dag} \cdot \mathrm{kg}^{-1}\right)$ and $\mathrm{Mg}\left(3.75\right.$ dag $\left.\cdot \mathrm{kg}^{-1}\right)$.

The content of $\mathrm{P}$ in the complete treatment, $0.53 \mathrm{dag} \cdot \mathrm{kg}^{-1}$ (i.e. $5.30 \mathrm{~g} \cdot \mathrm{kg}^{-1}$ ), is in agreement with [17], who indicated P content of 3 to $6 \mathrm{~g}^{\mathrm{kg}} \mathrm{kg}^{-1}$ to optimize the growth of most crops during the vegetative stage of growth. However, the plants that received treatment with the omission of phosphorus presented a significant reduction in the contents of $\mathrm{P}\left(0.07 \mathrm{dag} \cdot \mathrm{kg}^{-1}\right)$ and $\mathrm{Mg}\left(0.49 \mathrm{dag} \cdot \mathrm{kg}^{-1}\right)$ in relation

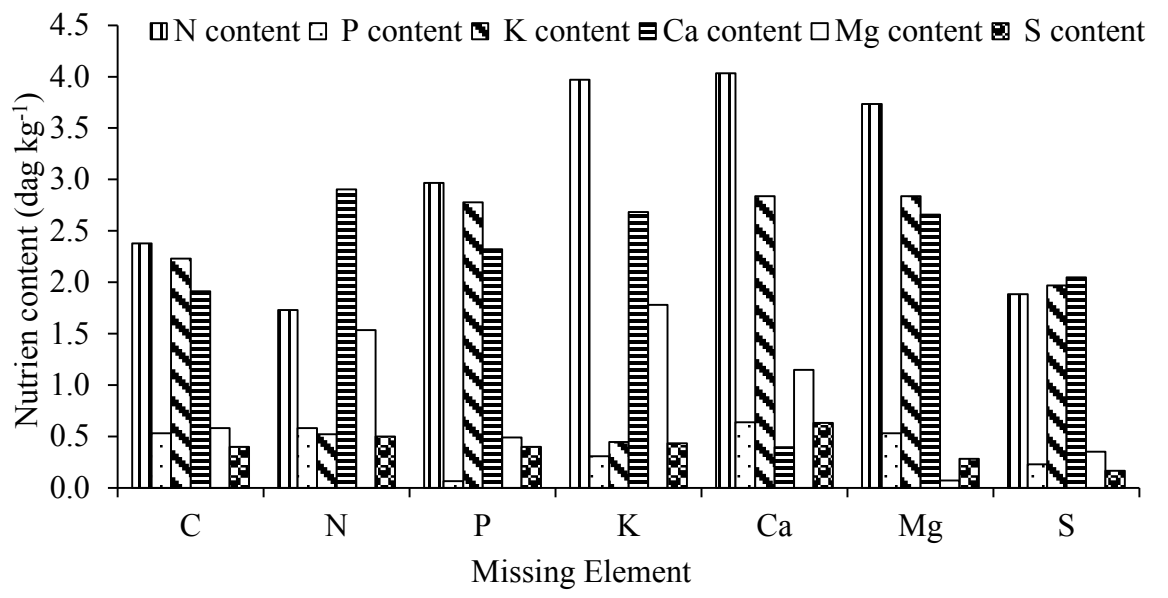

Figure 1. Nutrient contents of sunflower cv. BRS 122 submitted to eight treatments (C-complete solution, $\mathrm{N}$-solution without nitrogen, $\mathrm{P}-$ solution without phosphorus, $\mathrm{K}$-solution without potassium, $\mathrm{Ca}$-solution without calcium, $\mathrm{Mg}$-solution without magnesium, S-solution without S). NOTE: The averages followed by the same lowercase letter in the columns corresponding to each nutrient analyzed in the tissues do not differ statistically from each other by the Tukey test at $5 \%$ probability level. 
to the complete treatment. On the other hand, this did not occur in relation to $\mathrm{N}$ (2.97 dag. $\left.\mathrm{kg}^{-1}\right), \mathrm{K}\left(2.78 \mathrm{dag} \cdot \mathrm{kg}^{-1}\right), \mathrm{Ca}\left(2.32 \mathrm{dag} \cdot \mathrm{kg}^{-1}\right)$ and $\mathrm{S}\left(0.40 \mathrm{dag} \cdot \mathrm{kg}^{-1}\right)$, which were similar to the complete treatment (2.38 dag. $\mathrm{kg}^{-1}, 2.23 \mathrm{dag} \cdot \mathrm{kg}^{-1}, 1.91$ dag. $\mathrm{kg}^{-1}$ and 0.40 dag. $\mathrm{kg}^{-1}$, respectively) (Figure 1 ).

The omission of $\mathrm{K}$ in the nutrient solution decreased the levels of $\mathrm{P}(0.31$ dag. $\mathrm{kg}^{-1}$ ) and $\mathrm{K}\left(0.45 \mathrm{dag} \cdot \mathrm{kg}^{-1}\right)$, increased $\mathrm{N}$ (3.97 dag. $\left.\mathrm{kg}^{-1}\right), \mathrm{Mg}\left(1.78 \mathrm{dag} \cdot \mathrm{kg}^{-1}\right)$ and $\mathrm{S}\left(0.44 \mathrm{dag} \cdot \mathrm{kg}^{-1}\right)$, and maintained Ca content $\left(2.68 \mathrm{dag} \cdot \mathrm{kg}^{-1}\right)$ in plant tissues compared to the complete treatment (Figure 1). According to [13], the relationship of $\mathrm{K}$ with $\mathrm{Ca}$ and $\mathrm{Mg}$ in plants interacts among them due to their competition in the uptake by plants. Thus, it was observed that the omission of $\mathrm{K}$ presented a $\mathrm{Ca}+\mathrm{Mg} / \mathrm{K}$ ratio nine times higher (9.9) than in the complete treatment, which was 1.1. This fact indicates the nutritional imbalance in plants with deficiency of $\mathrm{K}$. However, the content of $\mathrm{K}$ in the complete treatment, 22.3 $\mathrm{g} \cdot \mathrm{kg}^{-1}$, is within the range considered adequate by [13], which is $20 \mathrm{~g} \cdot \mathrm{kg}^{-1}$ at 27 $\mathrm{g} \cdot \mathrm{kg}^{-1}$.

Plants that received the treatment with the omission of Ca presented only a decrease in $\mathrm{Ca}$ content $\left(0.40 \mathrm{dag} \cdot \mathrm{kg}^{-1}\right)$, in relation to the complete treatment (1.91 dag. $\mathrm{kg}^{-1}$ ) (Figure 1). The latter value is within the range of $1.7-2.2$ dag. $\mathrm{kg}^{-1}$, considered adequate by [13]. The increase in nutrient contents due to the omission of $\mathrm{Ca}$ in the nutrient solution can be explained by the concentration effect, because there was a higher concentration of nutrients $(\mathrm{N}, \mathrm{P}, \mathrm{K}, \mathrm{Mg}$ and S) in the plant tissues as a consequence of the lower plant growth.

It was observed that the plants submitted to the omission of $\mathrm{Mg}$ had lower levels of $\mathrm{Mg}\left(0.07 \mathrm{dag} \cdot \mathrm{kg}^{-1}\right)$ and $\mathrm{S}\left(0.28 \mathrm{dag} \cdot \mathrm{kg}^{-1}\right)$, higher $\mathrm{N}$ content $\left(3.73 \mathrm{dag} \cdot \mathrm{kg}^{-1}\right)$ and similar $\mathrm{P}$ contents $\left(0.53 \mathrm{dag} \cdot \mathrm{kg}^{-1}\right), \mathrm{K}\left(2.84 \mathrm{dag} \cdot \mathrm{kg}^{-1}\right)$ and $\mathrm{Ca}\left(2.66 \mathrm{dag} \cdot \mathrm{kg}^{-1}\right)$, compared to the complete treatment (Figure 1 ). The $\mathrm{Mg}$ content in complete treatment $\left(0.58 \mathrm{dag} \cdot \mathrm{kg}^{-1}\right.$, i.e. $\left.5.8 \mathrm{~g} \cdot \mathrm{kg}^{-1}\right)$ is within the range considered adequate by [18], which is $3.0-8.0 \mathrm{~g} \cdot \mathrm{kg}^{-1}$.

The plants that received the treatment with the omission of $\mathrm{S}$ presented decrease in the plant tissues of the contents of $\mathrm{N}\left(1.89 \mathrm{dag} \cdot \mathrm{kg}^{-1}\right), \mathrm{P}\left(0.23 \mathrm{dag} \cdot \mathrm{kg}^{-1}\right)$, $\mathrm{K}\left(1.97 \mathrm{dag} \cdot \mathrm{kg}^{-1}\right), \mathrm{Mg}\left(0.35 \mathrm{dag} \cdot \mathrm{kg}^{-1}\right)$ and $\mathrm{S}\left(0.17 \mathrm{dag} \cdot \mathrm{kg}^{-1}\right)$ and similar Ca content $\left(2.05 \mathrm{dag} \cdot \mathrm{kg}^{-1}\right)$, relative to the complete treatment (Figure 1). According to [19], sulfur deficiency reduces the amount of nitrogen converted to organic form, resulting in restriction to plant growth, because of the proportion of these nutrients in proteins.

According to Figure 1, the highest concentrations of $\mathrm{N}$ were observed in plants cultivated in solution with the omission of $\mathrm{Ca}\left(4.03 \mathrm{dag} \cdot \mathrm{kg}^{-1}\right), \mathrm{K}(3.97$ dag. $\mathrm{kg}^{-1}$ ) and $\mathrm{Mg}\left(3.75 \mathrm{dag} \cdot \mathrm{kg}^{-1}\right)$, followed by omissions of $\mathrm{P}\left(2.97 \mathrm{dag} \cdot \mathrm{kg}^{-1}\right), \mathrm{S}$ (1.89 dag. $\left.\mathrm{kg}^{-1}\right)$ and $\mathrm{N}\left(1.73 \mathrm{dag} \cdot \mathrm{kg}^{-1}\right)$ over the complete treatment which corresponded to $2.38\left(0.58 \mathrm{dag} \cdot \mathrm{kg}^{-1}\right)$ and $\mathrm{Mg}\left(0.53 \mathrm{dag} \cdot \mathrm{kg}^{-1}\right)$ were observed in the cultivated plants, with the exception of $\mathrm{Ca}\left(0.64 \mathrm{dag} \cdot \mathrm{kg}^{-1}\right)$ corresponding to the complete treatment $\left(0.53 \mathrm{dag} \cdot \mathrm{kg}^{-1}\right)$. The highest levels of $\mathrm{K}$ were observed in plants with the omission of $\mathrm{Ca}\left(2.84 \mathrm{dag} \cdot \mathrm{kg}^{-1}\right), \mathrm{Mg}\left(2.84 \mathrm{dag} \cdot \mathrm{kg}^{-1}\right)$ and $\mathrm{P}(2.78$ 
dag. $\left.\mathrm{kg}^{-1}\right)$. With the exception of the plants submitted to the omission of $\mathrm{Ca}(0.40$ dag. $\left.\mathrm{kg}^{-1}\right)$, in the other treatments there was no significant difference between the averages observed for the calcium content. The Mg content in the plants was the one that most varied among all the studied nutrients. The highest concentration of this element was observed for the treatment with omission of $\mathrm{K}$ (1.78 dag. $\mathrm{kg}^{-1}$ ) due to the antagonistic interaction between these nutrients. The levels of $\mathrm{S}$ in sunflower plants, both in the complete treatment and in the treatments with omission of the elements, were higher than those recommended by [18], which is $1.5-2.0 \mathrm{~g} \cdot \mathrm{kg}^{-1}$.

Finally, it was observed the following order of nutrient extraction of sunflower cv. BRS 122: $\mathrm{N}>\mathrm{K}>\mathrm{Ca}>\mathrm{Mg}>\mathrm{P}>\mathrm{S}$. These results indicate that $\mathrm{N}$ is the first and $\mathrm{K}$ is the second nutrient most required by sunflower plants.

\section{Conclusion}

The omission of $\mathrm{N}, \mathrm{P}, \mathrm{K}, \mathrm{Ca}, \mathrm{Mg}$ and $\mathrm{S}$ limited the dry mass production of sunflower $\mathrm{cv}$. BRS 122, in relation to the complete solution. In addition, they caused interaction between nutrients, leading to nutritional imbalance. The omission of the macronutrients $\mathrm{K}, \mathrm{Ca}$, and $\mathrm{Mg}$ caused the higher imbalances in the plants, highlighting the elevated $\mathrm{N}$ contents in these treatments comparing to the complete solution.

\section{Acknowledgements}

The authors acknowledge the National Council for Scientific and Technological Development (CNPq) for the financing of this research and the scholarship of the first author.

\section{Conflicts of Interest}

The authors declare no conflicts of interest regarding the publication of this paper.

\section{References}

[1] Castro, C., Castiglioni, V.B.R., Balla, A., Leite, R.M.V.B.C., Karam, D., Mello H.C., Guedes, L.C.A. and Farias, J.R.B. (1997) A cultura do girassol. EMBRAPA-CNPSo, Londrina (EMBRAPA-CNPSo. Circular Técnica, 13).

[2] Lira, M.A., Carvalho, H.W.L., Chagas, M.C.M., Bristot, G., Dantas, J.A. and Lima, J.M.P. (2011) Avaliação das potencialidades da cultura do girassol, como alternativa de cultivo no semiárido nordestino. EMPARN, Natal.

[3] Campos, V.B., Chaves, L.H.G. and Guerra, H.O.C. (2015) Adubação com NPK e irrigação do girassol em Luvissolo: Comportamento vegetativo. Revista Ambiente \& Água, 10, 221-233.

[4] Laviola, B.G. and Dias, L.A.S. (2008) Teor e acúmulo de nutrientes em folhas e frutos de pinhão-manso. Revista Brasileira de Ciências do Solo, 32, 1969-1975. https://doi.org/10.1590/S0100-06832008000500018

[5] Fageria, V.D. (2001) Nutrient Interactions in Crop Plants. Journal of Plant Nutri- 
tion, 24, 1269-1290. https://doi.org/10.1081/PLN-100106981

[6] McCauley, A., Jones, C. and Jacobsen, J. (2011) Plant Nutrient Functions and Deficiency and Toxicity Symptoms. Montana State University Extension Publications. http://landresources.montana.edu/nm/documents/NM9.pdf

[7] El-Ramady, H., Alshaal, T., Shehata, S.A., Domokos-Szabolcsy, É., Elhawat, N., Prokisch, J., Fári, M. and Marton, L. (2014) Plant Nutrition: From Liquid Medium to Micro-Farm. In: Ozier-Lafontaine, H. and Lesueur-Jannoyer, M., Eds., Sustainable Agriculture Reviews 14: Agroecology and Global Change, Springer, Switzerland, 449-508.

[8] Bezerra Neto, E. (2017) Cadernos do semiárido: Riquezas e oportunidades. Hidroponia. Conselho Regional de Engenharia e Agronomia de Pernambuco. 92 p. http://www.creape.org.br/portal/wp-content/uploads/2016/11/Caderno-6.pdf

[9] Borges, B.M.M.N., Flores, R.A., Almeida, H.J., Moda, L.R. and Prado, R.M. (2016) Macronutrient Omission and the Development and Nutritional Status of Basil in Nutritive Solution. Journal of Plant Nutrition, 39, 1627-1633. https://doi.org/10.1080/01904167.2016.1187742

[10] Hoagland, D.R. and Arnon, J.P. (1950) The Water Culture Method for Growing Plants without Soils. California Agricultural Experimental Station, Berkeley.

[11] Ferreira, D.F. (2011) SISVAR: A Computer Statistical Analysis System. Ciência e Agrotecnologia, 35, 1039-1042. https://doi.org/10.1590/S1413-70542011000600001

[12] Prado, R.M. and Leal, R.M. (2006) Desordens nutricionais por deficiência em girassol var. Catissol-011. Pesquisa Agropecuária Tropical, 36, 187-193.

[13] Malavolta, E., Vitti, G.C. and Oliveira, S.A. (1997) Avaliação do estado nutricional das plantas: Princípios e aplicações. 2nd Edition, Potafos, Piracicaba.

[14] Mengel, K. and Kirkby, E.A. (1987) Principles of Plant Nutrition. Intern, Postash Institute, Bem.

[15] Funk, J.L. and Amatangelo, K.L. (2013) Physiological Mechanisms Drive Differing Foliar Calcium Content in Ferns and Angiosperms. Oecologia, 13, 23-32. https://doi.org/10.1007/s00442-013-2591-1

[16] White, P.J. and Broadley, M.R. (2003) Calcium in Plants. Annals of Botany, 92, 487-511. https://doi.org/10.1093/aob/mcg164

[17] Marschner, H. (1995) Mineral nutrition of higher plants. 2nd Edition, Academic Press, London.

[18] Raij, B. Van., Andrade, J.C., Cantarella, H., Quaggio, J.A. and Furlani, A.M.C. (1996) Recomendações de adubação e calagem para o Estado de São Paulo. 2nd Edition, InstitutoAgronômico e Fundação IAC, Campinas.

[19] Andrew, C.S. (1977) The Effect of Sulphur on the Growth, Sulphur and Nitrogen Concentrations, and Critical Sulphur Concentrations of Some Tropical and Temperate Pasture Legumes. Australian Journal of Agricultural Research, 28, 807-820. https://doi.org/10.1071/AR9770807 